ISSN 1392-3196 / e-ISSN 2335-8947

Zemdirbyste-Agriculture, vol. 108, No. 2 (2021), p. 147-152

DOI 10.13080/z-a.2021.108.019

\title{
The prevalence of mycotoxins and their relation to nutrient composition of maize and grass silage
}

\author{
Eimantas VENSLOVAS, Lauksme MERKEVICIUTE-VENSLOVE, Audrone MANKEVICIENE, \\ Yuliia KOCHIIERU, Alvyra SLEPETIENE, Jurgita CESEVICIENE \\ Lithuanian Research Centre for Agriculture and Forestry \\ Instituto al. 1, Akademija, Kèdainiai distr., Lithuania \\ E-mail: eimantas.venslovas@lammc.lt
}

\begin{abstract}
In this study, samples of maize and grass silage were collected from various farms of Lithuania and were analysed for mycotoxins: aflatoxin $\mathrm{B}_{1}\left(\mathrm{AFB}_{1}\right)$, deoxynivalenol (DON), T-2 toxin (T-2) and zearalenone (ZEA), over the 2017-2019 period. Silage nutrient composition, including content of dry matter, crude protein, crude fibre, starch (for maize), and acidity $(\mathrm{pH})$ were investigated, and fermentation degree was computed.

All samples contained at least one mycotoxin, $85 \%$ of samples were co-contaminated with all four mycotoxins tested, $13 \%$ of samples contained three and only $1.5 \%$ of samples contained two mycotoxins. In general, the concentrations of DON, ZEA and T-2 were respectively 5, 1.7 and 2 times higher in maize silage than in grass one. Maize silage had the highest levels of ZEA and AFB, exceeding the European Union's (EU) maximum allowable limits. In grass silage, mycotoxin with the highest concentration exceeding the allowable limits was $\mathrm{AFB}_{1}$. Between the experimental years, statistically significant differences were found only in T-2 content in maize silage. Silage storage had an impact only on $\mathrm{AFB}_{1}$ concentrations: its highest concentration $\left(10.9 \pm 1.1 \mu \mathrm{g} \mathrm{kg}^{-1}\right)$ was found in trench silos, while in silage clamps and bales that ones were lower by $48 \%$ and $44 \%$, respectively. DON negatively correlated with dry matter in grass silage. ZEA negatively correlated with crude protein content and $\mathrm{pH}$ in maize silage and with dry matter and crude fibre content and $\mathrm{pH}$ in grass silage, but positively correlated with fermentation degree in both silages. T-2 negatively correlated with crude protein content and positively correlated with crude fibre content in grass silage.
\end{abstract}

Key words: aflatoxin $\mathrm{B}_{1}$, deoxynivalenol, nutrient composition, silage, $\mathrm{T}-2$ toxin, zearalenone.

\section{Introduction}

Silage is one of the key ingredients in the diet of ruminants and a vital source of proteins, nutrients, energy and fibre (Queiroz et al., 2012). As a result, most of the Northern European countries store forages as silage due to the wet climate conditions (Hutnik, Kobielak, 2012). It is known that control of silage production can be the key factor determining silage fermentation, but even under controlled conditions this process can be complex (Mogodiniyai et al., 2013). It is necessary to pay more attention to the quality and safety issues, as the feeding of poor-quality silages reduces animal productivity and endangers animal and human health (Stoškus et al., 2019). Aerobic instability of silage can adversely affect its hygienic quality by inducing the growth of moulds and mycotoxin formation, which may pose a risk to humans by possible transmission of pathogens and mycotoxins to animal products such as milk. In addition, a high ambient temperature can accelerate several aerobic microorganisms that further accelerate the process of silage deterioration (Ogunade et al., 2016; Borreani et al., 2018).

The most important crops used for ensiling are forage legumes, grasses and maize with grasses being more important in Europe and maize in North America Other crops used for ensiling are wheat, barley and industrial by-products: sugar beet tops, pressed sugar beet pulp, brewer's grains, ect. (Alonso et al., 2013). A recent 4-year mycotoxin survey in Poland revealed that up to $95 \%$ of feedstuffs contained at least one mycotoxin (Kosicki et al., 2016). Ensiled forages may contain a mixture of mycotoxins, originating from pre-harvest contamination by Fusarium and Aspergillus species (Uegaki et al., 2013; Gallo et al., 2015) and/or from postharvest contamination with toxigenic moulds such as Aspergillus and Penicillium species that are common in silage (Alonso et al., 2013).

A high dry matter content $(>50 \%)$ in the raw material makes the silage more susceptible to self-heating and infection with toxin-producing fungi. Advances in silage production technology are primarily related to maize whole plant and grain silage, the quality of which depends on the stage of growth. Delayed harvesting to achieve high dry matter content results in the growth of yeast and mould; thus, maize silage has the highest dynamics of changes in microbiological quality (Purwin et al., 2006). Therefore, it is very important that such silage is not contaminated with microscopic fungi and mycotoxins (Ogunade et al., 2016; Jatkauskas et al., 2018; Queiroz et al., 2018), because the weather conditions in

Please use the following format when citing the article:

Venslovas E., Merkeviciute-Venslove L., Mankeviciene A., Kochiieru Y., Slepetiene A., Ceseviciene J. 2021. The prevalence of mycotoxins and their relation to nutrient composition of maize and grass silage. Zemdirbyste-Agriculture, 108 (2): $147-152$. DOI 10.13080/z-a.2021.108.019 
Lithuania are favourable for the occurrence of fungi and for the contamination of animal feed with mycotoxins (Baliukonienè et al., 2012).

A preliminary study of ZEA and other mycotoxins in Australian silage showed that concentrations of mycotoxins are positively correlated with crude protein content and negatively correlated with neutral detergent fibre (Reed, Moore, 2009). Mycotoxin contamination levels in silage produced in Lithuania were reviewed by Baliukonienè et al. (2012). The survey revealed that the highest total concentration of aflatoxins was detected in ryegrass silage stored in bales. The highest ZEA concentration was detected in grass mixture silage from trenches, and the highest DON concentration was determined in clover silage from bales. A comparison of silage produced using different technologies showed that contamination with aflatoxins and DON was by $14 \%$ and $24 \%$ higher in silage samples from bales than that from trenches (Baliukoniene et al., 2012). It has been documented that fungal growth and mycotoxin concentration impact silage quality (Alonso et al., 2013 Dagnas et al., 2015; Schmidt et al., 2015; Jovaišienè et al., 2017). However, there is still a paucity of information about mycotoxin contamination levels of maize whole plant silage and grain silage and correlations between mycotoxin levels and silage nutrient composition.

The aim of the present study was to quantify mycotoxin contamination levels in maize and grass silage in Lithuania, ascertain how the weather conditions and silage storage influence silage contamination with mycotoxins, and to determine the correlations between mycotoxins and different silage nutrient composition parameters.

\section{Materials and methods}

Samples collection. Sixty-eight samples of whole plant maize $(n=58)$ and grass $(n=78)$ silage were collected from different regions of Lithuania between May 2017 and August 2019 at different seasons. All farms were selected randomly, including small and large farms. The types of silage sampled represented different regions of Lithuania. All samples were taken according to the standard procedures (European Commission, 2009). At the end of the ensiling season, 8 incremental samples of silage were taken from each currently used trench silo, clamp or bale. Using disposable gloves, each incremental sample was taken from various points and at a depth of about $30 \mathrm{~cm}$. An aggregate sample was about $4 \mathrm{~kg}$ in weight. The final sample (approx. $1 \mathrm{~kg}$ ) was made from the homogenised aggregate sample. The sample was placed in a clean plastic bag, vacuumed and sealed for transportation to the laboratory. All samples were stored at $4-8^{\circ} \mathrm{C}$ temperature. In total, 272 mycotoxin and 369 nutrient composition analyses were performed.

Mycotoxin analyses. The presence of four different mycotoxins in maize and grass silage was observed. The samples were analysed for mycotoxins deoxynivalenol (DON), zearalenone (ZEA), T-2 toxin (T-2) and aflatoxin $\mathrm{B}_{1}\left(\mathrm{AFB}_{1}\right)$ contamination by an enzyme linked immunosorbent assay (ELISA). The mycotoxins were quantified using competitive test kits Ridascreen $^{\circledR}$ No. R5901, R5502, R1211 and R5302 (RBiopharm, Germany), as instructed by the manufacturer. The analytical methods were validated by the kit's manufacturer with the sample matrices for maize and grass silage. The limit of detection (LOD) for DON is $200 \mu \mathrm{g} \mathrm{kg}^{-1}$, for ZEA - $17 \mu \mathrm{g} \mathrm{kg}^{-1}$, for T-2 - $50 \mu \mathrm{g} \mathrm{kg}^{-1}$ and for $A F B-1.0 \mu \mathrm{g} \mathrm{kg}^{-1}$. The method has been approved by the AOAC Research Institute (Certificate No. 950702). Mycotoxin analyses were done in duplicate. The optical densities of the samples and controls from a standard curve were estimated using a $450 \mathrm{~nm}$ filter by a multichannel photometer Multiskan Ascent (Thermo Electron Corp., Finland) supplied with internal software.

Nutrient composition of silage. Dry matter (DM), crude protein (CP), starch and crude fibre (CF) content and fermentation degree (FD) in silage were determined by near infrared spectroscopy (NIRS) by a NIRS-6500 device with a sample spinning module (Foss-Perstorp, USA) using wavelengths between 400 and $2500 \mathrm{~nm}$ in reflectance. For NIRS determination, the samples were chopped into $\sim 3 \mathrm{~cm}$ pieces, oven-dried at $65 \pm 5^{\circ} \mathrm{C}$ temperature to a constant weight and ground in an ultra-centrifugal mill ZM 200 (Retsch, Germany) to pass a $1 \mathrm{~mm}$ screen. The dried samples were scanned in triplicate using cuvettes, and the obtained spectra were processed with equations installed in the device (for maize silage - equation from VDLUFA laboratory, Germany; for grass silage - from ADAS, UK). The acidity $(\mathrm{pH})$ was measured on a liquid phase according to a potentiometric method using a $\mathrm{pH}$ meter (Horiba, UK). To determine DM content, the sample was dried at $105^{\circ} \mathrm{C}$ temperature until the weight was stable. FD was computed under the data of DM and $\mathrm{pH}$.

Meteorological conditions. In 2017, summer and autumn periods were wet and cool (Figure 1). Precipitation was markedly above the long-term average from June to October, except for August. Rainfall in July and September was twice as high as the long-term average and amounted to 153.3 and $123.1 \mathrm{~mm}$, when the long-term average is 76.6 and $64 \mathrm{~mm}$, respectively. In 2018, temperature averages of the summer months (June-August) ranged from $17.5^{\circ} \mathrm{C}$ to $20.5^{\circ} \mathrm{C}$ and were higher than the long-term average by $1.8,2.7$ and $2.7^{\circ} \mathrm{C}$, respectively. The amount of rainfall in June, August and September was respectively $34.1,37$ and $13.1 \mathrm{~mm}$, and it was nearly half lower than the long-term average: June $61.2 \mathrm{~mm}$, August $73.2 \mathrm{~mm}$ and September $65 \mathrm{~mm}$. In general, the year 2018 was very dry and rather warm. The period from June to September in 2019 was relatively dry and warm. The temperature was almost the same as longterm average, except for June, which was hotter than usual $20.6^{\circ} \mathrm{C}$, which is $5.2^{\circ} \mathrm{C}$ more than the long-term average. Rainfall in June and July was 16.0 and $66.0 \mathrm{~mm}$ lower than the long-term average. Moisture shortage and high temperature resulted in fast development of crops.

Statistical analysis was conducted using packages from the software IBM SPSS Statistics, version 25. Significant differences between mycotoxin concentrations in the samples were calculated using one-way ANOVA (LSD test). The values with $P \leq 0.05$ were considered significant. A confidence interval of $95 \%$ was measured, and figures were created with IBM SPSS Statistics. The Pearson correlation analysis was performed to examine the quantitative relationship between the investigated variables. The strength of the correlation was estimated according to the value of correlation coefficient $(r)$. Significance level (data were significant when $P \leq 0.05$ ) was calculated with a regression analysis tool in Excel. The data of mycotoxins and nutrient composition of silage were expressed as mean \pm standard error (SE) and median.

\section{Results and discussion}

Mycotoxin concentration differences in maize and grass silage. $\mathrm{DON}, \mathrm{ZEA}, \mathrm{T}-2$ and $\mathrm{AFB}$ were detected in all maize samples. DON was found in $74 \%$, AFB in $97 \%$ and ZEA and T-2 in all of grass silage samples. Maize and grass silage showed quantitative and qualitative differences regarding the nutrient composition and mycotoxin contamination (Tables 1 and 2). Except for AFB, the levels of all mycotoxins were higher in maize silage than in grass one. The differences in the concentrations of mycotoxins between these two types of silage were statistically significant $(P<0.05)$ for DON, 

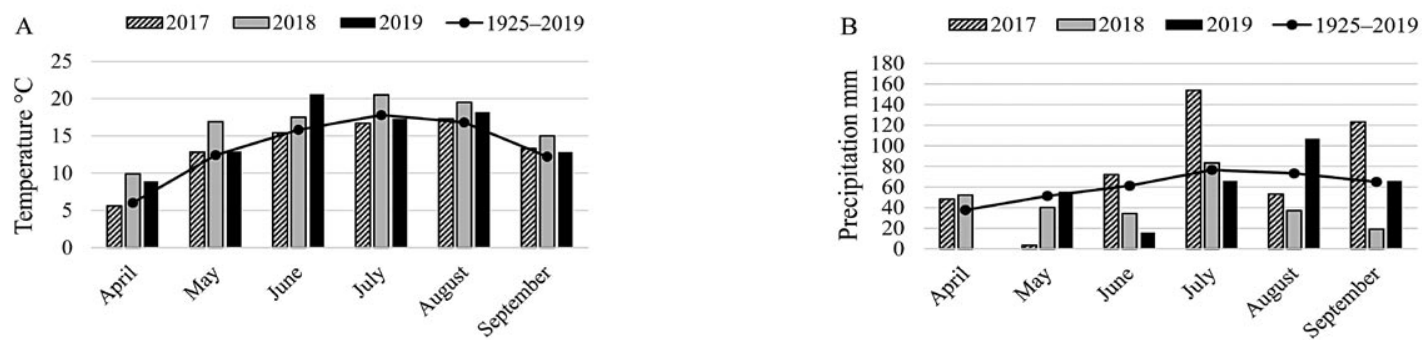

Figure 1. The average monthly air temperature (A) and precipitation (B) during the 2017-2019 growing seasons and long-term average (1925-2019)

Table 1. Nutrient composition of maize silage and concentrations of mycotoxins deoxynivalenol (DON), zearalenone (ZEA), $\mathrm{T}-2$ toxin (T-2) and aflatoxin $\mathrm{B}_{1}\left(\mathrm{AFB}_{1}\right)$ in 2017-2019

\begin{tabular}{|c|c|c|c|c|c|c|c|c|c|c|}
\hline & \multirow{2}{*}{$\begin{array}{c}\text { Dry matter } \\
\%\end{array}$} & Crude protein & Starch & Crude fibre & \multirow{2}{*}{$\mathrm{pH}$} & \multirow{2}{*}{$\begin{array}{c}\text { Fermentation } \\
\text { degree }\end{array}$} & DON & ZEA & $\mathrm{T}-2$ & AFB \\
\hline & & & DM \% & & & & \multicolumn{4}{|c|}{$\mu \mathrm{g} \mathrm{kg}^{-}$} \\
\hline $\operatorname{Mean}_{\mathrm{SE}}$ & $\begin{array}{l}39.8 \\
1.8\end{array}$ & $\begin{array}{l}8.10 \\
0.10\end{array}$ & $\begin{array}{l}32.2 \\
1.2\end{array}$ & $\begin{array}{l}19.3 \\
0.58\end{array}$ & $\begin{array}{l}4.1 \\
0.06\end{array}$ & $\begin{array}{l}26.8 \\
1.31\end{array}$ & $\begin{array}{c}2180 \\
356\end{array}$ & $\begin{array}{l}623 \\
39.5\end{array}$ & $\begin{array}{r}199 \\
20.8\end{array}$ & $\begin{array}{l}10.0 \\
1.2\end{array}$ \\
\hline Max & 60.8 & 9.50 & 42.1 & 26.8 & 5.4 & 30.0 & 8047 & 1235 & 467 & 27.4 \\
\hline Median & $\begin{array}{l}22.9 \\
39.0\end{array}$ & $\begin{array}{l}7.20 \\
8.00 \\
\end{array}$ & $\begin{array}{l}10.0 \\
32.0 \\
\end{array}$ & $\begin{array}{l}13.4 \\
19.5 \\
\end{array}$ & $\begin{array}{l}3.8 \\
4.0\end{array}$ & 28.8 & $\begin{array}{l}1271 \\
\end{array}$ & $\begin{array}{l}100 \\
625 \\
\end{array}$ & 200 & $7 .{ }^{1.0}$ \\
\hline
\end{tabular}

$\mathrm{SE}$ - standard error

Table 2. Nutrient composition of grass silage and concentrations of mycotoxins deoxynivalenol (DON), zearalenone (ZEA), T-2 toxin (T-2) and aflatoxin $\mathrm{B}_{1}\left(\mathrm{AFB}_{1}\right)$ in 2017-2019

\begin{tabular}{|c|c|c|c|c|c|c|c|c|c|}
\hline & \multirow{2}{*}{$\begin{array}{c}\text { Dry matter } \\
\%\end{array}$} & Crude protein & Crude fibre & \multirow{2}{*}{$\mathrm{pH}$} & \multirow{2}{*}{$\begin{array}{c}\text { Fermentation } \\
\text { degree }\end{array}$} & $\mathrm{DON}$ & \multirow{2}{*}{$\frac{\mathrm{ZEA}}{\mu \mathrm{g} \mathrm{k}}$} & \multirow{2}{*}{$\mathrm{T}-2$} & \multirow[t]{2}{*}{$\mathrm{AFB}_{1}$} \\
\hline & & & & & & & & & \\
\hline $\begin{array}{c}\text { Mean } \\
\text { SE } \\
\text { Max } \\
\text { Min } \\
\text { Median }\end{array}$ & $\begin{array}{r}45.8 \\
2.5 \\
86.1 \\
20.8 \\
43.6\end{array}$ & $\begin{array}{c}13.30 \\
0.70 \\
22.80 \\
5.60 \\
13.20\end{array}$ & $\begin{array}{r}27.3 \\
0.7 \\
35.7 \\
19.8 \\
27.2\end{array}$ & $\begin{array}{l}4.9 \\
0.1 \\
6.3 \\
4.0 \\
4.8\end{array}$ & $\begin{array}{c}11.7 \\
2.4 \\
29.6 \\
0.1 \\
16.5\end{array}$ & $\begin{array}{c}438 \\
74 \\
2386 \\
<\mathrm{LOD} \\
418\end{array}$ & $\begin{array}{r}376 \\
28.1 \\
683 \\
83 \\
374\end{array}$ & $\begin{array}{l}104 \\
15.1 \\
445 \\
\text { LOI } \\
74\end{array}$ & $\begin{array}{c}9.0 \\
1.1 \\
34.2 \\
1.3 \\
6.6\end{array}$ \\
\hline
\end{tabular}

$\mathrm{SE}$ - standard error; LOD - limit of detection

ZEA and T-2. The concentration of DON in maize silage was higher than that in grass one: $2180.0 \pm 356.0$ and $438.0 \pm 74.0 \mu \mathrm{g} \mathrm{kg}^{-1}$, respectively. The concentration of ZEA in maize silage $\left(623.0 \pm 39.5 \mu \mathrm{g} \mathrm{kg}^{-1}\right)$ was higher than that in grass silage $(376.4 \pm 28.1 \mu \mathrm{g} \mathrm{kg}-1)$. The concentration of T-2 in maize silage was $199.9 \pm 20.8 \mu \mathrm{g}$ $\mathrm{kg}^{-1}$ and in grass silage $-104.4 \pm 15.1 \mu \mathrm{g} \mathrm{kg}^{-1}$. All in all, DON, ZEA and T-2 concentrations were respectively 5, 1.7 and 2 times higher in maize silage than in grass one.

Our experimental data agree with those obtained in Poland: the concentration of DON in maize silage was 2 times, of ZEA - 19 times and of T-2 - 3 times higher than in grass silage (Panasiuk et al., 2019).

There is a lack of information about mycotoxins in silages made in Lithuania, but there are studies showing that moulds are more likely to grow in maize silage than in grass one, when no inoculant is used. This might come as a result of maize leaves and corncobs being richer in protein and polysaccharides than grass, so fungi and other pathogens can easily survive and spread on them (Zachariasova et al., 2014). While these data in our case were statistically significant, on the other hand, AFB content did not vary markedly between maize $(10.0 \pm$ $\left.1.2 \mu \mathrm{g} \mathrm{kg}^{-1}\right)$ and grass $\left(9.0 \pm 1.1 \mu \mathrm{g} \mathrm{kg}^{-1}\right)$ silage. A study in Spain (Rodríguez-Blanco et al., 2021) provided different results, as only 11 silage samples out of 95 were positive for at least one of the aflatoxins; aflatoxins were mostly detected in maize silage $(n=9)$.

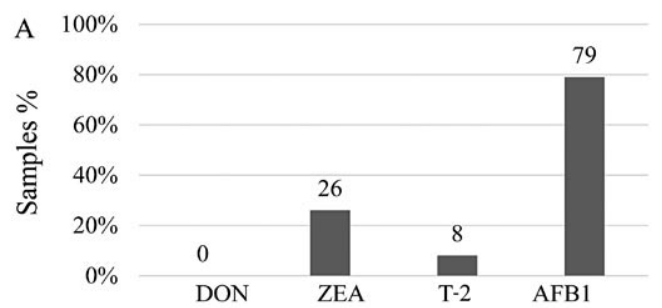

Samples exceeded the EU maximum limits set for mycotoxins. Due to the negative impact of mycotoxins on animal health, regulations have been set for mycotoxins in feed. In the EU, there are maximum limits set for AFB (European Commission, 2002) and the guidance levels for ZEA and DON (European Commission, 2006). Only $10 \%$ of maize silage samples exceeded DON recommendations, and the highest concentration was $8047 \mu \mathrm{g} \mathrm{kg}^{-1}$.

The rest of the mycotoxins surpassed the recommended limits in both types of silage (Figure 2). AFB and ZEA are a major concern, because 55 samples $(79 \%$ of grass and $86 \%$ of maize silage) and 33 samples ( $26 \%$ of grass and $79 \%$ of maize silage), respectively, exceeded the limits. The highest concentration of ZEA $\left(1235 \mu \mathrm{g} \mathrm{kg}^{-1}\right)$ was found in maize silage, and the highest concentration of $\mathrm{AFB}_{1}$ $\left(34.2 \mu \mathrm{g} \mathrm{kg}^{-1}\right)$ was determined in grass silage.

The research on maize silage conducted in other European countries revealed that none of 158 samples collected during a 5-year period (2014-2018) exceeded the $\mathrm{EU}$ guidance/maximum levels set for $\mathrm{DON}$ and $\mathrm{AFB}$; however, 8 of these samples were contaminated with ZEA, whose concentrations were above the recommended level $\left(\geq 2000 \mu \mathrm{g} \mathrm{kg}^{-1}\right)$ (Reisinger et al., 2019). Research in Spain (Rodríguez-Blanco et al., 2021) showed that none of the silage samples exceeded $\mathrm{AFB}_{1}, \mathrm{DON}$ and ZEA $\mathrm{EU}$ set guidance values. A possible reason for the high mycotoxin levels in locally made silage could be wet and cool weather conditions.

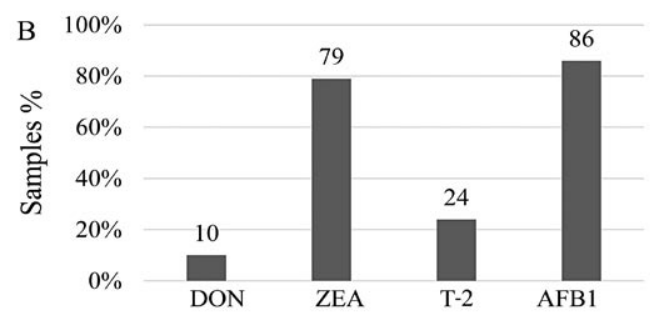

Figure 2. Grass (A) and maize (B) silage relative share of samples for mycotoxins deoxynivalenol (DON), zearalenone (ZEA), T-2 toxin (T-2) and aflatoxin $\mathrm{B}_{1}\left(\mathrm{AFB}_{1}\right.$ ) concentrations (in \%) exceeding the EU set guidance values in 2017-2019 
Effect of meteorological conditions. The levels of mycotoxins were compared depending on the year. Concentrations of mycotoxins between years showed statistically significant $(P<0.05)$ differences in T-2 concentrations in maize silage (Figure 3). In 2018, maize silage was less contaminated than in 2017 and 2019, but there were no significant differences between those years. In general, 2018 was very dry and warm compared to 2017 and 2019, therefore, there was less contamination with T-2. Comparison of the concentrations of other mycotoxins in different silages and years showed no significant differences.

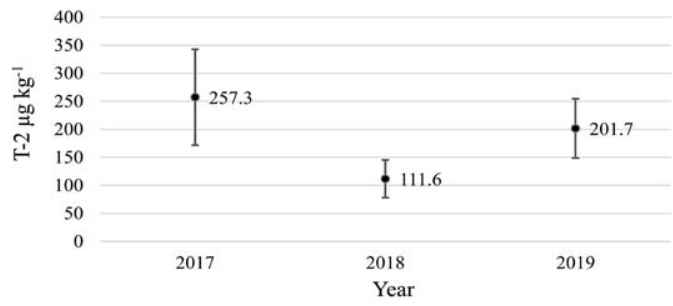

Note. Error bars show 95\% confidence interval; $\bullet$ - mean.

Figure 3. T-2 toxin (T-2) concentration in maize silage in 2017-2019

Other authors (Adhikari et al., 2017) suggest that production of trichothecenes depends on temperatures for fungal growth $\left(0-50^{\circ} \mathrm{C}\right)$, humidity $(70 \%)$, oxygen and moisture level of the growth medium, action of insects, flooding and rainfall during harvesting. Mycotoxin T-2 is produced mainly by Fusarium sporotrichioides and F. poae, but it can also be produced by other Fusarium species (Edwards et al., 2009). Heavy rainfall, wet climatic conditions and cool weather in late summer and early autumn lead to strong and widespread infection by Fusarium fungi and mycotoxins (Xu et al., 2014; Gupta, 2018).

The impact of silage storage. Significant differences $(P<0.05)$ in AFB concentrations were found while analysing the impact of silage storage (Figure 4). $\mathrm{AFB}_{1}$ concentrations were 1.9 and 1.8 times higher in trench silos than in silage clamps and bales. The concentration of AFB in trench silos was $10.9 \pm 1.1 \mu \mathrm{g}$ $\mathrm{kg}^{-1}$, while in silage clamps it was $5.7 \pm 0.4 \mu \mathrm{g} \mathrm{kg}^{-1}$ and in bales $-6.1 \pm 0.74 \mu \mathrm{g} \mathrm{kg}^{-1}$. However, no significant changes were observed with other mycotoxins.

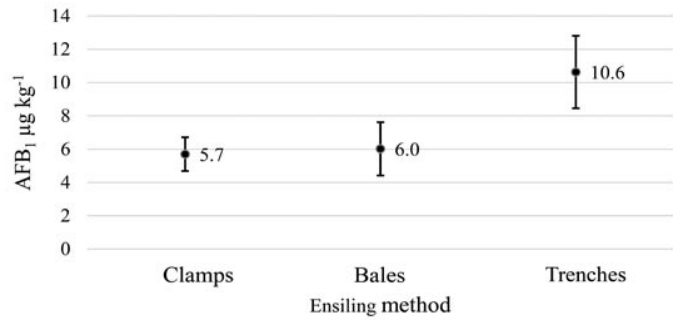

Note. Error bars show 95\% confidence interval; $\bullet$ - mean.

Figure 4. The impact of silage storage on aflatoxin $B_{1}$ $\left(\mathrm{AFB}_{1}\right)$ concentration in 2017-2019

Comparison of silo bales and trench silos done by other researchers showed that when handling is appropriate, mycotoxin and fungal contamination in silage bales is significantly lower than in trench silos. However, if the plastic baler is damaged or handling is improper, the amount of the dominant and toxigenic species increases, which can speed up deterioration (González Pereyra et al., 2007). Other studies have found that aflatoxins are predominant in trench silos, because silage in trenches is more exposed to environmental conditions (González Pereyra et al., 2011).

Silage quality. The dry matter (DM) content was higher in grass silage $(45.8 \pm 2.5 \%)$ than in maize silage
$(39.8 \pm 1.8 \%)$, while grass silage DM is typically between $25-35 \%$ and maize silage DM - between 30-40\% (Kung, Shaver, 2001; Sirvydis, 2004). Higher crude protein (CP) content was determined in grass silage $(13.3 \pm 0.7 \% \mathrm{DM})$ compared with maize silage $(8.1 \pm 0.1 \% \mathrm{DM})$, while for good quality grass silage CP content should be around 15-18\% DM (Sirvydis, 2004). Maize silages are relatively low in CP. Maize silage quality research shows variation in $\mathrm{CP}$ content depending on maize species $7.4-7.9 \%$ (Khan et al., 2012; 2015). Crude fibre (CF) content was higher in grass silage $(27.3 \pm 0.7 \% \mathrm{DM})$ than in maize silage $(19.3$ $\pm 0.58 \% \mathrm{DM})$. Starch content in maize silage amounted to $32.2 \pm 1.2 \% \mathrm{DM}$, which on average is supposed to be around 22-26\% DM (Shaver, 2007; Butkutè, Gaurilčikaitè, $2008)$. Higher acidity $(\mathrm{pH})$ had grass silage $(4.9 \pm 0.1)$ than maize silage $(4.08 \pm 0.06)$, while good quality grass silage a $\mathrm{pH}$ has from 4.3 to 4.7 and maize silage - from 4.0 to 4.5 (Kung, Shaver, 2001). However, maize silage was characterized by a higher fermentation degree (FD), which was $26.8 \pm 1.31$ compared with grass silage, where FD was $11.7 \pm 2.4$. FD above 19.45 is considered to show great quality of silage stability (Butkutè, Gaurilčikaitè, 2008). Similar results were obtained by other researchers (Köhler et al., 2013; 2019)

Correlations. The Pearson correlation coefficients, used to determine the relationship between nutrient composition and mycotoxins in maize or grass silages, are presented in Table 3. A negative moderate correlation was found between ZEA concentrations and $\mathrm{pH}$ in maize $(r=-0.57, P<0.01)$ and grass $(r=-0.54$, $P<0.01)$ silage. A positive moderate correlation between ZEA concentrations and FD was found in silage of maize $(r=0.54, P<0.01)$ and grass $(r=0.45, P<0.01)$.

Mycotoxin concentration depends on mould species and $\mathrm{pH}$ of the medium, and the highest mycotoxin concentrations can be found even at low $\mathrm{pH}$ values (Sandoval-Cotreras et al., 2017). Also, different organic acids have diverse impact on mould growth (Dagnas et al., 2015; Jovaišienè et al., 2017), which might explain the results obtained in our study.

In grass silage, DON and ZEA concentrations negatively moderately correlated with dry matter $(r=$ $-0.50, P<0.01$ and $r=-0.48, P<0.01$, respectively). One of the highest risks of conserved forages is fungal spoilage and mycotoxin contamination. Fungal growth causes loss of nutrients and dry matter, which induces the losses in animal performance (Alonso et al., 2013). The findings of Schmidt et al. (2015) showed a low correlation $(r=0.24)$ between DM and ponderal mycotoxin index (PMI). When the DM is ideal, harvesting maize probably contributes to lower mycotoxin concentrations. It is possibly because of the shorter field time, if compared with high maturity plants harvested two weeks (or even more) later.

A weak negative correlation was found between ZEA and CP content in maize silage $(r=-0.39, P<0.05)$. Almost of the same strength negative correlation was found in grass silage between T-2 concentrations and CP content $(r=-0.38, P<0.05)$. The same trend was noted by other researchers from Lithuania and Poland (Jovaišienė et al., 2017), who documented that mycotoxin concentrations weakly negatively correlated with $\mathrm{CP}$ content. A weak negative correlation was found in grass silage between ZEA concentrations and CF content $(r=-0.34, P<0.05)$; however, a positive correlation was found in the same silage between T-2 concentrations and $\mathrm{CF}$ content $(r=0.37, P<0.05)$. However, no significant correlations between the $\mathrm{AFB}_{1}$ concentrations and silage nutrient composition parameters were found.

Diverse correlation results in different silages could occur, because moulds are more likely to grow in maize silage than in grass one, when no inoculant is used. This might come as a result of maize leaves and corncobs being richer in protein and polysaccharides than grass, so fungi and other pathogens can easily survive and spread on them (Zachariasova et al., 2014). 
Table 3. Correlation coefficients $(r)$ between nutrient composition and mycotoxins deoxynivalenol (DON), zearalenone (ZEA), T-2 toxin (T-2) and aflatoxin $\mathrm{B}_{1}\left(\mathrm{AFB}_{1}\right)$ concentrations in maize and grass silage samples in 2017-2019

\begin{tabular}{|c|c|c|c|c|c|}
\hline \multicolumn{6}{|c|}{ Maize silage } \\
\hline Mycotoxin & DM \% & $\begin{array}{c}\text { Crude protein } \\
\text { DM \% }\end{array}$ & $\begin{array}{l}\text { Crude fibre } \\
\text { DM \% }\end{array}$ & $\mathrm{pH}$ & $\begin{array}{c}\text { Fermentation } \\
\text { degree }\end{array}$ \\
\hline DON & -0.08 & -0.07 & -0.04 & -0.24 & 0.26 \\
\hline $\mathrm{ZEA}$ & -0.08 & $-0.39 *$ & 0.04 & $-0.57 * *$ & $0.54 * *$ \\
\hline $\mathrm{T}-2$ & -0.24 & 0.04 & 0.09 & 0.02 & 0.01 \\
\hline $\mathrm{AFB}_{1}$ & -0.29 & 0.04 & 0.08 & -0.21 & 0.20 \\
\hline \multicolumn{6}{|c|}{ Grass silage } \\
\hline Mycotoxin & DM \% & $\begin{array}{c}\text { Crude protein } \\
\text { DM \% }\end{array}$ & $\begin{array}{c}\text { Crude fibre } \\
\text { DM \% }\end{array}$ & $\mathrm{pH}$ & $\begin{array}{c}\text { Fermentation } \\
\text { degree }\end{array}$ \\
\hline DON & $-0.50 * *$ & 0.12 & -0.26 & -0.13 & 0.01 \\
\hline ZEA & $-0.48 * *$ & -0.04 & $-0.34 *$ & $-0.54 * *$ & $0.45 * *$ \\
\hline T-2 & 0.12 & $-0.38^{*}$ & $0.37 *$ & -0.05 & 0.06 \\
\hline $\mathrm{AFB}_{1}$ & -0.20 & -0.25 & 0.04 & -0.07 & 0.05 \\
\hline
\end{tabular}

$\mathrm{DM}$ - dry matter; * $-P \leq 0.05$ and $* *-P \leq 0.01$ significance level

\section{Conclusions}

1. Maize silage was found to be more susceptible to mycotoxin contamination than grass silage. This was particularly evident in the assessment of contamination with deoxynivalenol (DON) and zearalenone (ZEA).

2. The most prevalent mycotoxins in grass and maize silages were aflatoxin $\mathrm{B}_{1}\left(\mathrm{AFB}_{1}\right)$ and $\mathrm{ZEA}$, whose levels exceeded the EU set guidance levels.

3 . In 2018, the growing season was very dry and warm compared with the other growing seasons observed, which resulted in a lower contamination with $\mathrm{T}-2$ toxin $(\mathrm{T}-2)$.

4. Comparison of silage storages revealed significantly higher concentrations of $\mathrm{AFB}_{1}$ in trench silos than in clamps or bales.

5. DON negatively correlated with dry matter (DM) in grass silage. ZEA negatively correlated with crude protein $(\mathrm{CP})$ content and acidity $(\mathrm{pH})$ in maize silage and with DM and crude fibre (CF) content and $\mathrm{pH}$ in grass silage, but positively correlated with fermentation degree (FD) in both silages. T-2 negatively correlated with CP and positively correlated with $\mathrm{CF}$ in grass silage.

Further research is needed to cover broader silage sampling sites and to match silage quality and safety requirements.

\section{Acknowledgements}

This study was supported by the long-term research programs "Harmful Organisms in Agro- and Forest Ecosystems" and "Biopotential and Quality of Plants for Multi-functional Use" implemented by Lithuanian Research Centre for Agriculture and Forestry, and the project "Quality diagnostics of biogas production by-product (digestate) for innovative use as a biofertilizer" No. DOTSUT-217 (01.2.2-LMT-K-71801-0053 (LMTLT).

Received 13102020 Accepted 19012021

\section{References}

Adhikari M., Negi B., Kaushik N., Adhikari A., AlKhedhairy A. A., Kaushik N. K., Choi H. E. 2017. T-2 mycotoxin: toxicological effects and decontamination strategies. Oncotarget Open Access Impact Journal, $8(20) \cdot 33032-33052$

https://doi.org/10.18632/oncotarget.15422

Alonso A. V., Pereyra C. M., Kelier L. A. M., Dalcero A. M., Rosa C. A. R., Chiacchiera S. M., Cavaglieri L. R. 2013. Fungi and mycotoxins in silage: an overview. Journal of Annlied Mirrohinlogy 115 (3): 637-643. https://doi.org/10.1111/jam.12178

Baliukoniene $\bar{v}$., Bakutis $\bar{B}$., Vaivadaitė T., Bartkienè $\mathrm{E}$. Jovaišiene J. 2012. Prevalence of fungi and mycotoxins in silage and milk in Lithuania. Veterinarija ir zootechnika, 59 (81): 3-9.

Borreani G., Tabacco E., Schmidt R. J., Holmes B. J., Muck R. E. 2018. Factors affecting dry matter and quality losses in silages. Iournal of Dairy Science, 101 (5): 3952-3979. https://doi.org/10.3168/jds.2017-13837
Butkutè B., Gaurilčikaite R. 2008. Quality and feeding value of maize silage produced in Lithuania. Veterinarija ir zootechnika, 41 (63): 32-41 (in Lithuanian). https://vetzoo. lsmuni.lt/data/vols/2008/41/pdf/butkute.pdf

Dagnas S., Gauvry E., Onno B., Membré J. 2015. Quantifying effect of lactic, acetic, and propionic acids on growth of molds isolated from spoiled bakery products. Journal of Fond Protection $78(9) \cdot 1689-1698$ https://doi.org/10.4315/0362-028X.JFP-15-046

Edwards S. G., Barrier-Guillot B., Clasen P. E., Hietaniemi V., Pettersson H. 2009. Emerging issues of HT-2 and T-2 toxins in European cereal nroduction World Mycotoxin Inurnal, 2 (2): 173-179. https://doi.org/10.3920/WMJ2008.1126

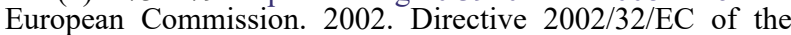
European Parliament and of the Council of 7 May 2002 on undesirable substances in animal feed. Official Journal of the European Union, L140, 10-22. https://eur-lex.europa.eu/ legal-content/EN/TXT/PDF/?uri=CELEX:02002L0032$20131227 \&$ from $=\mathrm{EN}$

European Commission. 2006. Commission recommendation of of 17 August 2006 on the presence of deoxynivalenol, zearalenone, ochratoxin a, T-2 and Ht-2 and fumonisins in products intended for animal feeding (2006/576/EU). Official Journal of the European Union, L229, 7-9. https:// eur-lex.europa.eu/LexUriServ/LexUriServ.do?uri=OJ: $\mathrm{L}: 2006: 229: 0007: 0009: \mathrm{EN}: \mathrm{PDF}$

European Commission. 2009. Commission Regulation (EC) No 152/2009 of 27 January 2009 laying down the methods of sampling and analysis for the official control of feed (text with EEA relevance). Official Journal of the European Union. https://eur-lex.europa.eu/legal-content/EN/TXT/ $\mathrm{PDF} /$ ?uri=CELEX:32009R0152\& from=EN

Gallo A., Giuberti G., Frisvard J. C., Bertuzzi T., Nielsen K. F. 2015. Review on mycotoxin issuse in ruminants: occurence in forages, effects of mycotoxin ingestion on health status and animal performance and practical strategies to counteract their negative effects Toxins $7(8) \cdot 3057-3111$. https://doi.org/10.3390/toxins708305787

González Pereyra M. L., Alonso V. A., Sager R., Morlaco M. B., Magnoli C. E., Astoreca A. L., Rosa C.A. R., Chiacchiera S. M. Dalcero A. M., Cavaglieri L. R. 2007. Fungi and selected mycotoxins from pre- and postfermented corn silage. Journal of Annlied Microhiology 104 (4): 1034-1041. https://doi.org/10.1111/j.1365-2672.2007.03634.x

Gonzälez Pereyra M. L., Chiacchiera S. M., Kosa C. A. R., Sager R., Dalcero A., Dalcero A. M., Cavaglieri L. 2011. Comparative analysis of the mycobiota and mycotoxins contaminating corn trench silos and silo bags. Journal of the Science of Fond and Agriculture, 91 (8): 1474-1481. https://doi.org/10.1002/jsfa.4336

Gupta K. C. 2018. Veterinary loxicology ( $3^{\text {rd }}$ ed.). Academic Press n $1043-1053$ https://doi.org/10.1016/B978-0-12-811410-0.00075-1

Hutnik E., Kobielak S. 20I2. Density of silage stored in horizontal silos. Acta Agrophysica, 19 (3): 539-549.

Jatkauskas J., Vrotniakienė V., Stoškus R. 2018. Variations in fermentation, bacterial population and aerobic stability in maize silage Zemdirhvste-A griculture 105 (4): 377-382. https://doi.org/10.13080/z-a.2018.105.048

Jovaisiene J., Bakutis B., Baliukoniene V., Matusevičius P., Lipiński K., Antoszkiewicz Z., Fijałkowska M. 2017. Biogenic amines and mycotoxins concentrations in baled silage from organic and conventional farms. Arquivo Brasileirn de Medicina Veterinária e Znontecnia, 69 (2):269-277. https://doi.org/10.1590/1678-4162-9130 
Khan N. A., Cone J. W., Fievez V., Hendriks W. H. 2012. Causes of variation in fatty acid content and composition in grass and maize silages Animal Feed Srience and Terhnolnoy $174(1$ 2): 36-45. https://doi.org/10.1016/j.anifeedsci.2012.02.006

Khan N. A., Yu Y., Ali M., Cone J. W., Hendriks W. H. 2015. Nutritive value of maize silage in relation to dairy cow performance and milk quality. Journal of the Science of Fond and Agriculture, 92 (2): 238-252. https://doi.org/10.1002/jsfa.6703

Köhler B., Diepolder M., Ustertag J., Thurner S., Spiekers H. 2013. Dry matter losses of grass, lucerne and maize silages in hunker silos Aoricultural and Fond Science, 22: 145-150. https://doi.org/10.23986/afsci.6715

Köhler B., laube F., Ustertag J., Ihurner S., Kluß C., Spiekers H. 2019. Dry-matter losses and changes in nutrient concentrations in grass and maize silages stored in bunker silos Grass and Forage Srience, 74 (2): 274-283. https://doi.org/10.1111/gfs. 12430

Kosick1 K., Błajet-Kosicka A., Grajewski J., Twarużek M. 2016. Multiannual mycotoxin survey in feed materials and feedingstuffs. Animal Feed Science and Terhnology, 215: 165180. https://doi.org/10.1016/j.anifeedsci.2016.03.012

Kung L., Shaver K. 2001. Interpretation and use ot slage fermentation analysis reports. Focus on Forage, 3 (13): 1-5. https://fyi. extension.wisc.edu/forage/files/2016/10/Fermentation2.pdf

Mogodiniyai K. K., Rustas B. O., Spörndly R., Udén P. 2013. Prediction models of silage fermentation products on crop composition under strict anaerobic conditions: a metaanalysis Inurnal of Dairy Srience 96 (10): 6644-6649. https://doi.org/10.3168/jds.2013-6858

Ogunade I. M., Arrıola K. G., Jiang Y., Driver J. P., Staples C. R., Adesogan A. T. 2016. Effects of 3 sequestering agents on milk aflatoxin $\mathrm{M}_{1}$ concentration and the performance and immune status of dairy cows fed diets artificially contaminated with aflatoxin $\mathrm{B}_{1}$. Inurnal of Dairy Srience, 99 (8): 6263-6273. https://doi.org/10.3168/jds.2016-10905

Panasiuk L., Jedziniak P., Pietrszka K., Piatkowska M. Bocian L. 2019. Frequency and levels of regulated and emerging mucotoxins in silage in Poland Mycotoxin Research, 35:17-25. https://doi.org/10.1007/s12550-018-0327-0

Purwin C., Łaniewska-I rokenheim L., Warminska-Kadyko I., Tywonczuk J. 2006. Silage quality: microbiological, healtpromoting and production aspects: review. Medycyna Weterynaryjna, 62 (8): 865-869 (in Polish). http://www. medycynawet.edu.pl/images/stories/pdf/pdf2006/08/ 20068s08650869.pdf

Queiroz O. C. M., Adesogan A. T., Arriola K. G., Queiroz M. F. S. 2012. Effect of a dual-purpose inoculant on the quality and nutrient losses from maize silage produced in farm-scale silos Inurnal of Dairy Science 95 (6) 3354-3362. https://doi.org/10.3168/jds.2011-5207

QueiroZ U. C. M., Ugunade I. M., Weinberg Z., Adesogan A. T. 2018. Silage review: Foodborne pathogens in silage and their mitigation by silage additives. Journal of Dairy Science 101 (5). 4132-4142

https://doi.org/10.3168/jds.2017-13901

Reed K. M., Moore D. 2009. A preliminary survey of zearalenone and other mycotoxins in Australian silage and nasture Animal Production Science, 49 (8): 696-703. https://doi.org/10.1071/EA08164

Reisinger N., Waldheim S., Mayer E., Debevere S. Antonissen G., Sulyok M., Nagl V. 2019. Mycotoxin occurrence in maize silage - a neglected risk for bovine gut health? Tnxins $11(10) \cdot 577$ https://doi.org/10.3390/toxins 11100577

Rodriguez-Bianco M., Kamos A. J., Sanchis V., Marín S. 2021. Mycotoxins occurrence and fungal populations in different types of silages for dairy cows in Snain Fungal Rinloov 175 (2): 103-114. https://doi.org/10.1016/j.funbio.2019.08.006

Sandoval-Cotreras 1., Villarruel-Lopez A., Sierra-Beitran A. P., Torres-Vitela R., Ascencio F. 2017. Effect of $\mathrm{pH}$ and temperature in production of mycotoxins and antibiotics by phytopathogenic moulds for Persian lime (Citrus latifolia $\mathrm{T}$.) in a complex lime pericarp-base medium. Emirates Journal of Fond and Aoriculture $29(10) \cdot 751-750$ https://doi.org/10.9755/ejfa.2017.v29.i10.1293

Schmidt P., Novinski C. U., Junges D., Almeida K., de Souza C. M. 2015. Concentration of mycotoxins and chemical composition of corn silage: a farm survey using infrared thermography. Inurnal of Dairy Science 98 (9): 6609-6619. https://doi.org/10.3168/jds.2014-8617

Shaver K. $200 \%$ Evaluatıng corn slage quality for dairy cattle. University of Wisconsin, USA, 10 p. https://fyi.extension.wisc. edu/forage/files/2016/10/EvaluatingCornSilageforDairy-1.pdf

Sirvydis J. 2004. Siloso gamintojo žinynas. Lietuvos žemès ūkio universitetas, 40 p. (in Lithuanian).

Stoškus R., Jatkauskas J., Vrotniakienè V., Juozaitienė V. 2019. The effect of mixed bacterial inoculant on the microbial population and aerobic stability of lucerne and maize balage Inurnal of Animal and Feed Sciences, 28 (4): 383 391. https://doi.org/10.22358/jafs/114138/2019

Uegaki K., Isukiboshi 1., Iohno M. 2013. Changes in the concentrations of fumonisin, deoxynivalenol and zearalenone in corn silage during ensilage Animal Science Journal, 84 (9): 656-662. https://doi.org/10.1111/asj.12053

$\mathrm{Xu} \mathrm{X}$. Madden L. V., Edwards S. G 2014 Modeling the effects of environmental conditions on HT2 and T2 toxin accumulation in field nat grains. Phvtonathology 104 (1): 57-66. https://doi.org/10.1094/PHYTO-03-13-0070-R

Zachariasova M., Dzuman Z., Veprikova Z., Halkova K., Jiru M., VaclavikovaM.,ZachariasovaA.,Pospichalova M., Florian M., Hajslova J. 2014. Occurrence of multiple mycotoxins in European feedingstuffs, assessment of dietary intake by farm animals Animal Feed Science and Technology, 193: 124-140. https://doi.org/10.1016/j.anifeedsci.2014.02.007

\title{
Mikotoksinų paplitimas ir jų ryšys su kukurūzų ir žolių siloso kokybès rodikliais
}

\author{
E. Venslovas, L. Merkevičiūtè-Venslovė, A. Mankevičienė, Y. Kochiieru, A. Šlepetienė, J. Cesevičienė
}

Lietuvos agrarinių ir miškų mokslų centras

\section{Santrauka}

Šiam tyrimui 2017-2019 m. iš įvairiu Lietuvos ūkių buvo paimti kukurūzų ir žolių siloso mėginiai. Juose buvo nustatytos mikotoksinu aflatoksino $\mathrm{B}_{1}(\mathrm{AFB})$, deoksinivalenolio (DON), T-2 toksino ir zearalenono (ZEA) koncentracijos. Taip pat buvo tirta siloso mitybinè vertė: sausujų medžiagų, žalių baltymų, žalios ląstelienos bei krakmolo kiekis, rūgštumas $(\mathrm{pH})$ ir apskaičiuotas fermentacijos laipsnis.

Visuose meginiuose buvo nustatytas bent vienas mikotoksinas, $85 \%$ mėginiu buvo užkrèsti visais keturiais, 13 $\%$ mėginiu - trimis ir 1,5\% - dviem tirtais mikotoksinais. Kukurūzu silose DON koncentracija buvo 5 kartus, ZEA - 1,7 karto, T-2 - 2 kartus didesnè nei žolių silose. Kukurūzų silosas pasižymėjo didžiausiomis ZEA ir AFB koncentracijomis, kurios viršijo Europos Sajungos nustatytas didžiausias leistinas normas. Žoliu silose šias normas viršijo mikotoksinas $\mathrm{AFB}_{1}$. Mikotoksinu kiekius vertinant skirtingais tyrimo metais, esminiais skirtumais pasižymëjo tik T-2 toksino koncentracijos. Vertinant skirtingus silosavimo būdus nustatyta, kad jie turi esminès įtakos mikotoksino AFB kiekiui: didžiausia jo koncentracija $\left(10,9 \pm 1,1 \mu \mathrm{g} \mathrm{kg}^{-1}\right)$ nustatyta iš tranšejos paimtuose siloso méginiuose, o mėginiuose, kurie buvo paimti iš kaupu ir ritinių, AFB koncentracija buvo atitinkamai 48 ir $44 \%$ mažesnè. DON kiekis neigiamai koreliavo su žolès siloso sausuju medžiagu kiekiu, ZEA kiekis neigiamai koreliavo su žalių baltymų kiekiu bei pH rodikliu kukurūzų silose ir su sausųjų medžiagų, žalios ląstelienos kiekiu bei pH rodikliu žolès silose. ZEA kiekis teigiamai koreliavo su fermentacijos laipsnio rodikliu ir kukurūzu, ir žolès silose. Žolių silose T-2 kiekis neigiamai koreliavo su žalių baltymų ir teigiamai - su žalios ląstelienos kiekiu.

Reikšminiai žodžiai: aflatoksinas $\mathrm{B}_{1}$, deoksinivalenolis, kokybès rodikliai, silosas, T-2 toksinas, zearalenonas. 